\title{
Changes induced by sucrose administration on glucose metabolism in pancreatic islets in normal hamsters
}

\author{
M L Massa, M I Borelli, H Del Zotto and J J Gagliardino \\ CENEXA - Centre of Experimental and Applied Endocrinology (UNLP-CONICET, PAHO/WHO Collaborating Center), University of La Plata \\ School of Medicine, La Plata, Argentina \\ (Requests for offprints should be addressed to J J Gagliardino, CENEXA (UNLP-CONICET), Facultad de Ciencias Médicas, Calles 60 y 120,1900 La Plata, \\ Argentina; Email: gagliardino@infovia.com.ar)
}

\begin{abstract}
We correlated the changes in glucose-induced insulin secretion with those observed in glucose metabolism and hexokinase/glucokinase activity in islets from normal sucrose-fed hamsters. Blood glucose and insulin levels were measured in normal male hamsters fed with (S5) or without (C5) 10\% sucrose in the drinking water for 5 weeks. Isolated islets (collagenase digestion) from both groups of animals were used to study insulin secretion, ${ }^{14} \mathrm{CO}_{2}$ and ${ }^{3} \mathrm{H}_{2} \mathrm{O}$ production from $\mathrm{D}-\left[\mathrm{U}_{-}{ }^{14} \mathrm{C}\right]$-glucose and $\mathrm{D}-\left[5-{ }^{3} \mathrm{H}\right]$-glucose respectively, with $3 \cdot 3$ or $16 \cdot 7 \mathrm{mM}$ glucose in the medium, and hexokinase/glucokinase activity (fluorometric assay) in islet homogenates.

Whereas S5 and C5 animals had comparable normal blood glucose levels, S5 showed higher insulin levels than C5 hamsters $(2 \cdot 3 \pm 0 \cdot 1$ vs $0 \cdot 6 \pm 0.03 \mathrm{ng} / \mathrm{ml}, \quad P<0 \cdot 001)$. Islets from S5 hamsters released significantly more insulin than C5 islets in the presence of low and high glucose $(3.3 \mathrm{mM}$ glucose: $0.77 \pm 0.04$ vs $0.20 \pm 0.06 \mathrm{pg} / \mathrm{ng}$ $\mathrm{DNA} / \mathrm{min}, P<0.001 ; 16.7 \mathrm{mM}$ glucose: $2 \cdot 77 \pm 0 \cdot 12 \mathrm{vs}$ $0.85 \pm 0.06 \mathrm{pg} / \mathrm{ng} \mathrm{DNA} / \mathrm{min}, P<0.001)$ and produced significantly higher amounts of ${ }^{14} \mathrm{CO}_{2}$ and ${ }^{3} \mathrm{H}_{2} \mathrm{O}$ at both glucose concentrations $\left({ }^{14} \mathrm{CO}_{2}: \quad 3 \cdot 3 \mathrm{mM}\right.$ glucose: $0 \cdot 27 \pm 0 \cdot 01$ vs $0 \cdot 18 \pm 0 \cdot 01, P<0 \cdot 001 ; 16 \cdot 7 \mathrm{mM}$ glucose: $1.44 \pm 0.15$ vs $0.96 \pm 0.08, \quad P<0.02 ;{ }^{3} \mathrm{H}_{2} \mathrm{O}: \quad 3.3 \mathrm{mM}$ glucose: $0.31 \pm 0.02$ vs $0.15 \pm 0.01, P<0.001 ; 16.7 \mathrm{mM}$ glucose: $1.46 \pm 0.20$ vs $0.76 \pm 0.05 \mathrm{pmol}$ glucose $/ \mathrm{ng}$
\end{abstract}

DNA/min, $P<0 \cdot 005)$. The hexokinase $K_{\mathrm{m}}$ and $\mathrm{V}_{\max }$ values from $\mathrm{S} 5$ animals were significantly higher than those from C5 ones $\left(K_{\mathrm{m}}: 100 \cdot 14 \pm 7 \cdot 01\right.$ vs $59 \cdot 90 \pm$ $3.95 \mu \mathrm{M}, P<0.001 ; \mathrm{V}_{\max }: 0.010 \pm 0.0005$ vs $0.008 \pm$ $0.0006 \mathrm{pmol}$ glucose $/ \mathrm{ng}$ DNA/min, $P<0 \cdot 02)$. Conversely, the glucokinase $K_{\mathrm{m}}$ value from $\mathrm{S} 5$ animals was significantly lower than in $\mathrm{C} 5$ animals $\left(\mathrm{K}_{\mathrm{m}}\right.$ : $15 \cdot 31 \pm 2.64$ vs $35.01 \pm 1.65 \mathrm{mM}, P<0 \cdot 001)$, whereas $\mathrm{V}_{\max }$ figures were within a comparable range in both groups $\left(\mathrm{V}_{\max }: \quad 0.048 \pm 0.009\right.$ vs $0.094 \pm 0.035 \mathrm{pmol}$ glucose/ng DNA/min, not significant). The glucose phosphorylation ratio measured at 1 and $100 \mathrm{mM}$ (hexokinase/glucokinase ratio) was significantly higher in S5 $(0 \cdot 26 \pm 0.02)$ than in C5 animals $(0 \cdot 11 \pm 0 \cdot 01$, $P<0 \cdot 005)$, and it was attributable to an increase in the hexokinase activity in S5 animals.

In conclusion, sucrose administration increased the hexokinase/glucokinase activity ratio in the islets, which would condition the increase in glucose metabolism by $\beta$-cells, and in $\beta$-cell sensitivity and responsiveness to glucose. These results support the concept that increased hexokinase rather than glucokinase activity causes the $\beta$-cell hypersensitivity to glucose, hexokinase being metabolically more active than glucokinase to up-regulate $\beta$-cell function.

Journal of Endocrinology (2001) 171, 551-556

\section{Introduction}

Glucose homeostasis depends on the balance between insulin secretion and the response of the target tissues to the hormone. This balance is further modulated by different hormones and metabolites, physical activity, physiological states and dietary components (Like \& Chick 1970, Stauffacher et al. 1970, Lombardo et al. 1983, Parsons et al. 1992, Luo et al. 1998).

Among those modulators, insulin resistance is a common denominator of several pathological conditions (Reaven 1988) that can strongly affect glucose homeostasis and islet function (DeFronzo 1997). Under its influence, normal blood glucose levels can only be achieved by attaining high levels of circulating insulin. To cope with this increased demand for insulin, islets undergo marked functional and morphological changes, increasing the release of insulin in response to glucose and the $\beta$-cell mass (Lombardo et al. 1996, Massa et al. 1997, Pick et al. 1998).

In this regard, we have demonstrated that administration of sucrose to both normal rats (Lombardo et al. 1996, Pick et al. 1998) and hamsters (Massa et al. 1997, Del Zotto et al. 1999) induces insulin resistance, which in time triggers an increase in insulin secretion and in the $\beta$-cell 
mass through an increase in the replication rate of $\beta$-cells and islet neogenesis. These changes were accompanied by a significant increase in the content of islet neogenesisassociated protein (INGAP) (Del Zotto et al. 2000), a cellular compound originally described by Vinik et al. (1996, 1997). However, we do not know the possible mechanism by which all these changes occurred.

Glucose-induced insulin release results from an increase in the rate of glucose metabolism in pancreatic $\beta$-cells (Ashcroft et al. 1970). Since the kinetics of glucose transport in the islets rapidly equilibrates its concentration across the cell membrane (Thorens et al. 1990), glucose phosphorylation becomes the rate-limiting step in the control of glucose metabolism. Further phosphorylation of glucose in the islets depends on the activity of two different kinases: hexokinase and glucokinase (Lenzen 1992, Lenzen \& Panten 1988, Matschinsky 1990) of low and high Michaelis constant $(\mathrm{Km})$ for glucose respectively.

Because of this knowledge and in an attempt to further characterize the mechanism by which sucrose administration modifies the secretory function of the islets, we have currently studied insulin secretion elicited by glucose, glucose metabolism $\left({ }^{14} \mathrm{CO}_{2}\right.$ production from $\mathrm{U}_{-}{ }^{14} \mathrm{C}$-glucose and ${ }^{3} \mathrm{H}_{2} \mathrm{O}$ production from ${ }^{3} \mathrm{H}$-glucose), and the hexokinase/glucokinase activity in islets isolated from normal hamsters fed with or without sucrose.

\section{Materials and Methods}

\section{Chemicals and drugs}

Collagenase was obtained from Serva Feinbiochemica, Heidelberg, Germany; D- $\left[\mathrm{U}_{-}{ }^{14} \mathrm{C}\right]$-glucose and D- $\left[5-{ }^{3} \mathrm{H}\right]-$ glucose $(10 \mu \mathrm{Ci} / \mathrm{ml}(300 \mu \mathrm{Ci} / \mathrm{mM}))$ were from $\mathrm{New}$ England Nuclear, Boston, MA, USA; bovine serum albumin (fraction V; BSA) and other reagents of the purest grade available were from Sigma Chemical Co., St Louis, MO, USA.

\section{Experimental groups}

Male Syrian hamsters of 23 days of age ( $30 \pm 2 \mathrm{~g})$, maintained in a temperature-controlled room $\left(23^{\circ} \mathrm{C}\right)$ with a fixed $12 \mathrm{~h}$ light: $12 \mathrm{~h}$ darkness cycle (lights on 0600$1800 \mathrm{~h}$ ), were randomly divided into two groups of 20 animals each. The treated group had free access to a standard commercial diet plus $10 \%(\mathrm{w} / \mathrm{v})$ sucrose in the drinking water for 5 weeks (S5), whereas the control group received the same diet and tap water for the same period (C5). Water intake was measured daily in both groups, while individual body weight was recorded once a week throughout the experimental period. The experiments were carried out in tissues from different animals from both control and treated groups.

\section{Blood measurements and pancreas removal}

At the time of death, blood samples were obtained from each animal (retro-orbital plexus) for determination of glucose (glucose-oxidase GOD-PAP method; Roche Diagnostics, Mannheim, Germany) and radioimmunoactive insulin levels by radioimmunoassay (RIA) (Herbert et al. 1965). The whole pancreas was also removed from each animal to isolate islets by collagenase digestion (Lacy \& Kostianovsky 1967). The islets obtained from each isolation were used to study insulin secretion, glucose metabolism and enzymatic activity in different assays.

\section{Insulin secretion in vitro}

Groups of five isolated islets were incubated for $60 \mathrm{~min}$ at $37^{\circ} \mathrm{C}$ in $0.6 \mathrm{ml} \mathrm{Krebs-Ringer} \mathrm{bicarbonate} \mathrm{buffer} \mathrm{(KRB),}$ $\mathrm{pH} 7 \cdot 4$, previously gassed with a mixture of $\mathrm{CO}_{2} / \mathrm{O}_{2}$ $(5 \% / 95 \%)$ and containing $1 \%(\mathrm{w} / \mathrm{v})$ BSA and different concentrations of glucose ( 3.3 and $16.7 \mathrm{mM}$ ) (Gagliardino et al. 1974). At the end of the incubation period, aliquots were taken from the medium to measure insulin by RIA (Herbert et al. 1965), using an antibody against rat insulin standard (Linco Research Inc., St Charles, MO, USA), and highly purified porcine insulin labelled with ${ }^{125} \mathrm{I}$ (Linde et al. 1980). Using this procedure, parallel tracerdisplacement curves were obtained using either the rat insulin standard, or partially purified insulin extracted from a pool of hamster pancreata (Massa et al. 1997).

\section{Glucose oxidation and utilization}

Groups of 20 islets were incubated in a glass vial containing $40 \mu \mathrm{l} \mathrm{KRB}$ buffer supplemented with $10 \mathrm{mM}$ Hepes $(\mathrm{pH}$ $7 \cdot 4)$ containing $\mathrm{D}-\left[\mathrm{U}_{-}{ }^{14} \mathrm{C}\right]$-glucose and $\mathrm{D}-\left[5-{ }^{3} \mathrm{H}\right]$-glucose $(10 \mu \mathrm{Ci} / \mathrm{ml}(300 \mu \mathrm{Ci} / \mathrm{mM}))$ in the presence of $3 \cdot 3$ or $16.7 \mathrm{mM}$ glucose. This vial was placed inside an airtightsealed $20 \mathrm{ml}$ glass scintillation vial $(500 \mu \mathrm{l}$ distilled water in the bottom) which contained another empty glass vial; after $2 \mathrm{~h}$ at $37^{\circ} \mathrm{C}$ the reaction was stopped by adding $20 \mu \mathrm{l}$ metabolic poison (400 $\mathrm{mM}$ citric acid, $10 \mathrm{mM}$ rotenone, $10 \mathrm{mM}$ antimycine and $3 \mathrm{mg} \mathrm{KCN}, \mathrm{pH} 4.9$ injected through the rubber seal) to the incubation vial; at the same time $250 \mu \mathrm{l}$ hyamine was added to the empty tube. After incubation for $60 \mathrm{~min}$ at $37^{\circ} \mathrm{C}$, the ${ }^{14} \mathrm{CO}_{2}$ fixed to hyamine was measured in vials containing $5 \mathrm{ml}$ scintillation liquid. The islets were then incubated overnight at room temperature and glucose utilization was measured as ${ }^{3} \mathrm{H}_{2} \mathrm{O}$ production captured by water in $5 \mathrm{ml}$ scintillation liquid. The reaction tube was frozen at $-20{ }^{\circ} \mathrm{C}$ (Malaisse \& Sener 1988).

\section{Hexokinase/glucokinase assay}

Groups of 20 isolated islets were homogenized (1 islet/ $\mu$ l) in Hepes- $\mathrm{NaOH}$ buffer $(50 \mathrm{mM}, \mathrm{pH} 7 \cdot 5)$ containing 
$6 \mathrm{mM} \mathrm{MgCl} 2,60 \mathrm{mM} \mathrm{KCl}, 10 \mathrm{mM} \mathrm{KH} \mathrm{PO}_{4}, 1 \mathrm{mM}$ EDTA, $1 \mathrm{mM}$ L-cysteine and $0.02 \%$ BSA. Twenty microlitres of islet homogenate were dropped into another $20 \mu \mathrm{l}$ of the reaction mixture (Hepes- $\mathrm{NaOH}, 10 \mathrm{mM}$ ATP, $20 \mu \mathrm{Ci} / \mathrm{ml}(300 \mu \mathrm{Ci} / \mathrm{mM}) \mathrm{D}-\left[\mathrm{U}-{ }^{14} \mathrm{C}\right]$-glucose and 1-100 $\mathrm{mM}$ unlabelled $\mathrm{D}$-glucose) and incubated for $60 \mathrm{~min}$ at $37^{\circ} \mathrm{C}$. The reaction was stopped by the addition of $1 \mathrm{ml}$ iced water and the diluted reaction medium was then passed through a column of AG 1-X8 (0.5 ml; Bio-Rad Laboratories, Hercules, CA, USA) to separate $\mathrm{D}-\left[\mathrm{U}_{-}{ }^{14} \mathrm{C}\right]$-glucose-6-phosphate from $\mathrm{D}-\left[\mathrm{U}_{-}{ }^{14} \mathrm{C}\right]$-glucose by ion exchange chromatography (Giroix et al. 1984). The column was later rinsed with $5 \times 1 \mathrm{ml}$ water, and the hexose phosphate was eluted with $3 \cdot 0 \mathrm{ml} 1 \mathrm{M}$ ammonium formate $/ 0 \cdot 1 \mathrm{M}$ formic acid. The eluate was mixed with $10 \mathrm{ml}$ scintillation fluid (Ultima Gold XR; Packard, Meriden, CT, USA) and its radioactive content was determined. Blank values were obtained under identical conditions but in the absence of islet homogenate. Only $0.5 \%$ of the initial radioactivity was found in such control samples. Using this procedure, the enzymic activity measured in the presence of low (up to $1 \mu \mathrm{M}$ ) and high glucose concentrations corresponded to hexokinase and glucokinase respectively.

\section{DNA content}

Several $10 \mu \mathrm{l}$ aliquots of islet homogenates from C5 and S5 hamsters were collected in tubes and stored at $-70{ }^{\circ} \mathrm{C}$ for subsequent measurements of DNA content by the fluorometric assay described by Labarca \& Paigen (1980).

\section{Statistical analysis}

The experimental data were analyzed using Student's $t$-test. Data are expressed as the means \pm s.E.M. Differences were considered significant when $P<0 \cdot 05$.

\section{Results}

\section{Body weight and water intake}

Similar body weights were recorded in S5 $(n=20)$ and C5 $(n=20)$ animals $(66 \cdot 1 \pm 8 \cdot 6$ vs $68 \cdot 3 \pm 7 \cdot 2 \mathrm{~g})$ at the end of the experiment. Animals from the S5 group drank a significantly larger volume of water than those from the C5 group $(30 \cdot 4 \pm 3 \cdot 7$ vs $22 \cdot 1 \pm 1 \cdot 3 \mathrm{ml} /$ day, $P<0 \cdot 001)$.

\section{Blood glucose and serum insulin levels}

There were no significant differences in the glucose levels measured at the time of death in both groups of animals (S5 $(n=20): 5 \cdot 7 \pm 0 \cdot 3$ vs C5 $(n=20): 5 \cdot 9 \pm 0 \cdot 22 \mathrm{mM})$. Conversely, S5 hamsters showed higher insulin levels than C5 hamsters $(2 \cdot 3 \pm 0 \cdot 1$ vs $0 \cdot 6 \pm 0 \cdot 03 \mathrm{ng} / \mathrm{ml} \quad(n=20$ animals in each group), $P<0 \cdot 001)$.

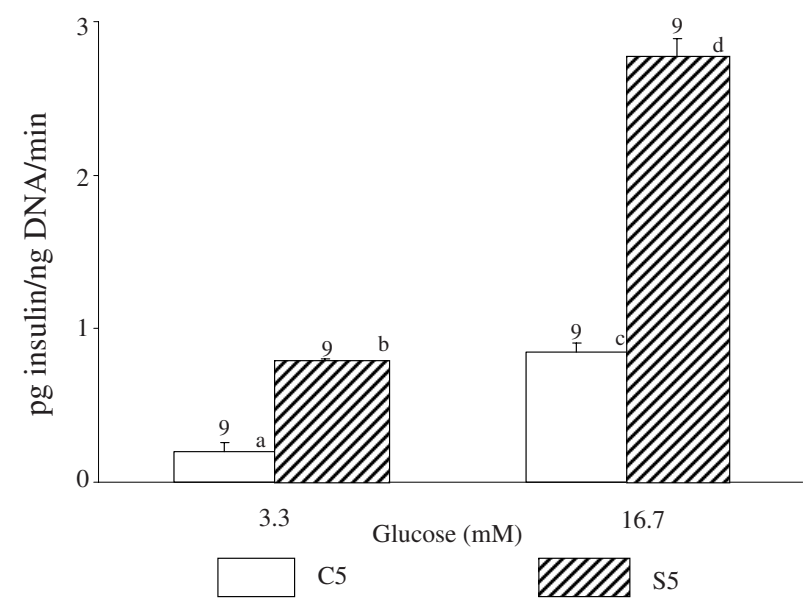

Figure 1 Insulin secretion (pg insulin/ng DNA/min) is represented in each group as the mean value \pm S.E.M.; the number of cases is shown above each bar, and was obtained in three different experiments performed with islets isolated from six hamsters from each experimental group. $P<0 \cdot 001$ : a vs $b$ and $c$ vs $d$.

Since blood glucose levels were comparable in S5 and C5 animals, the uneven serum insulin values increased the insulin-glucose molar ratio in the S5 group, as compared with the corresponding control values $\left(2 \cdot 24 \times 10^{-6}\right.$ vs $5 \cdot 6 \times 10^{-7}$ respectively).

\section{Insulin secretion}

Islets incubated with high glucose released significantly more insulin than those incubated with low glucose in both groups. On the other hand, islets isolated from S5 hamsters released significantly larger amounts of insulin than those from $\mathrm{C} 5$ animals in response to either a low or high glucose concentration $(3.3 \mathrm{mM}$ glucose: $0.77 \pm$ $0 \cdot 04$ vs $0.20 \pm 0.06 \mathrm{pg}$ insulin/ng DNA/min, $P<0 \cdot 001$; $16 \cdot 7 \mathrm{mM}$ glucose: $2 \cdot 77 \pm 0 \cdot 12$ vs $0.85 \pm 0.06 \mathrm{pg}$ insulin/ ng DNA/min, $P<0 \cdot 001$ ) (in all cases $n=9$ ) (Fig. 1).

\section{Glucose metabolism}

The production of ${ }^{14} \mathrm{CO}_{2}$ from $\mathrm{D}-\left[\mathrm{U}_{-}{ }^{14} \mathrm{C}\right]$-glucose and ${ }^{3} \mathrm{H}_{2} \mathrm{O}$ from $\mathrm{D}-\left[5_{-}{ }^{3} \mathrm{H}\right]$-glucose by the isolated islets increased significantly when the glucose concentration in the incubation medium was raised from 3.3 to $16 \cdot 7 \mathrm{mM}$ in both experimental groups. Both ${ }^{14} \mathrm{CO}_{2}$ and ${ }^{3} \mathrm{H}_{2} \mathrm{O}$ production was significantly higher in islets isolated from $\mathrm{S} 5$ than from C5 animals in the presence of either low or high glucose in the medium $\left({ }^{14} \mathrm{CO}_{2}: 3.3 \mathrm{mM}\right.$ glucose: $0 \cdot 27 \pm 0 \cdot 01 \quad(n=11)$ vs $0 \cdot 18 \pm 0 \cdot 01 \quad(n=12), \quad P<0 \cdot 001$; $16.7 \mathrm{mM}$ glucose: $1.44 \pm 0.15 \quad(n=18)$ vs $0.96 \pm 0.08$ $(n=18)$ pmol glucose/ng DNA/min, $P<0 \cdot 02 ;{ }^{3} \mathrm{H}_{2} \mathrm{O}$ : $3.3 \mathrm{mM}$ glucose: $0.31 \pm 0.02 \quad(n=18)$ vs $0 \cdot 15 \pm 0 \cdot 01$ $(n=18), P<0 \cdot 001 ; 16 \cdot 7 \mathrm{mM}$ glucose: $1 \cdot 46 \pm 0 \cdot 20(n=18)$ 

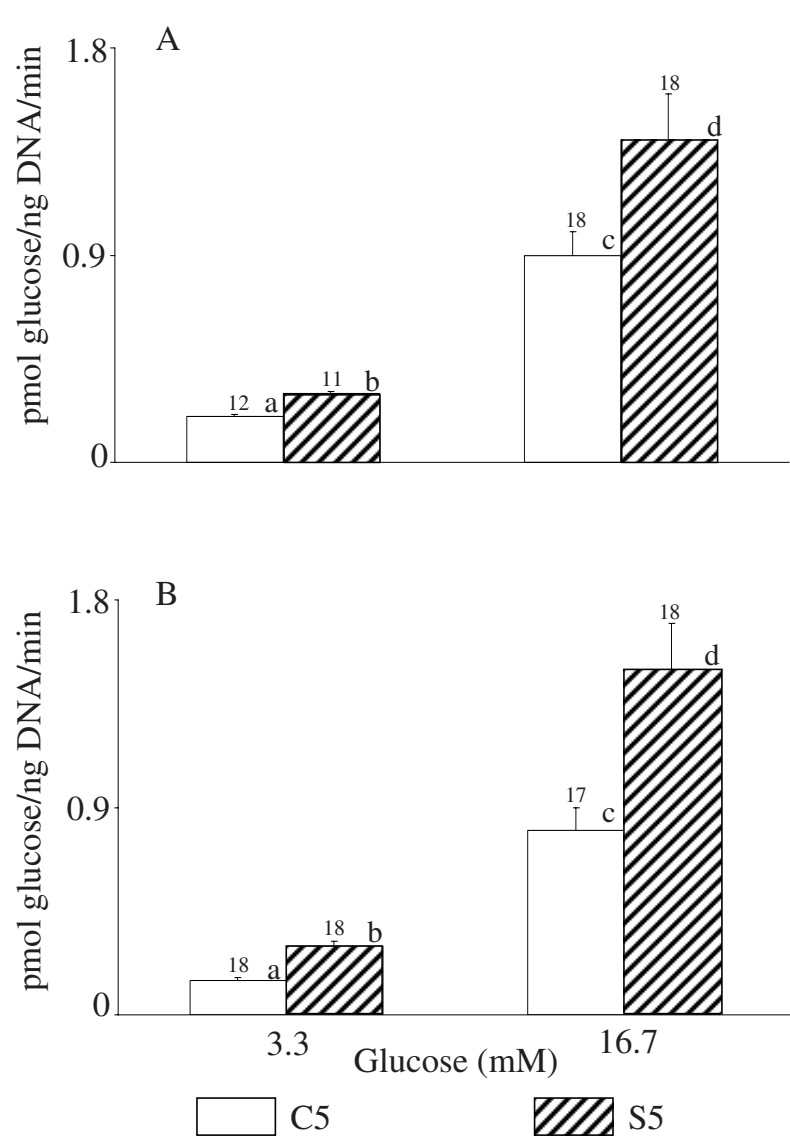

Figure 2 (A) Glucose oxidation and (B) glucose utilization measured as ${ }^{14} \mathrm{CO}_{2}$ from D-[U- $\left.{ }^{14} \mathrm{C}\right]$-glucose and ${ }^{3} \mathrm{H}_{2} \mathrm{O}$ from $\mathrm{D}-\left[5{ }^{3} \mathrm{H}\right]$-glucose respectively. Each group represents the mean value \pm S.E.M. expressed as pmol glucose/ng DNA/min. The number of cases is shown above each bar, and was obtained in three different experiments performed with islets isolated from six hamsters from each experimental group. $P<0.001$ in $A$ and $B$ : a vs $\mathrm{b}$ and $\mathrm{c}$ vs $\mathrm{d}$.

vs $0.76 \pm 0.05 \quad(n=17)$ pmol glucose/ng DNA/min, $P<0 \cdot 005)$ (Fig. 2A and $\mathrm{B}$ respectively).

\section{Hexokinase and glucokinase activity}

At increasing concentrations of glucose (up to $1 \mathrm{mM}$ ), the rate of glucose phosphorylation by islet homogenates was compatible with the participation of a hexokinase-like enzyme, with a $K_{\mathrm{m}}$ for glucose close to $59 \mu \mathrm{M}$. On the other hand, when increasing the concentration of glucose up to $100 \mathrm{mM}$, the rate was compatible with the participation of a glucokinase-like enzyme, with a $K_{\mathrm{m}}$ close to $35 \mathrm{mM}$. The $K_{\mathrm{m}}$ of hexokinase measured in S5 vs C5 islets $(100 \cdot 14 \pm 7 \cdot 01$ vs $59 \cdot 90 \pm 3.95 \mu \mathrm{M}, P<0 \cdot 001)$ as well as its maximal velocity $\left(\mathrm{V}_{\max }\right)(0 \cdot 010 \pm 0 \cdot 0005$ vs $0 \cdot 008 \pm 0.0006 \mathrm{pmol}$ glucose $/ \mathrm{ng} \mathrm{DNA} / \mathrm{min}, \quad P<0.02$, $25 \%$ increase) were significantly higher in S5 islets
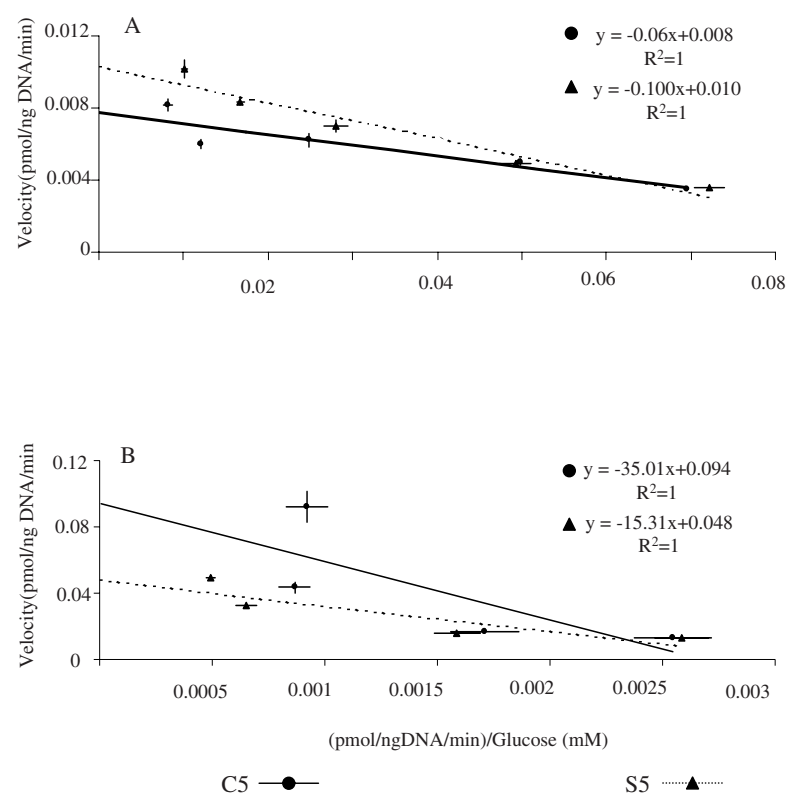

Figure 3 Glucose phosphorylation kinetics of islet homogenates. Each value represents the mean of 12 replicates performed in four different experiments with islets isolated from eight hamsters from each experimental group. The plot $\left(\mathrm{vi}=K_{\mathrm{m}} \times \mathrm{vi} /\right.$ Eadie-Hofstee $\mathrm{S}+\mathrm{V}_{\max }$ ) (where vi is initial velocity and $\mathrm{S}$ is substrate concentration) was used to estimate the $K_{\mathrm{m}}$ and $V_{\max }$ values for hexokinase and glucokinase. In both experimental groups (A) hexokinase activity was measured at 0.05, 0.01, 0.25 0.5 and $1 \mathrm{mM}$ glucose, while (B) glucokinase activity was tested at 5, 10, 50 and $100 \mathrm{mM}$ glucose. The comparison of vi/S values (means \pm S.E.M.) for hexokinase and glucokinase measured at each glucose concentration within each experimental group showed significant differences $(P<0 \cdot 001)$, except in the case of $50 \mathrm{vs}$ $100 \mathrm{mM}$ glucose in the control group (C5).

(Fig. 3A). Conversely, glucokinase $K_{\mathrm{m}}$ from S5 was significantly lower than that from C5 islet homogenates $(15 \cdot 31 \pm 2 \cdot 64$ vs $35 \cdot 01 \pm 1.65 \mathrm{mM}, P<0 \cdot 001)$, whereas no significant differences in $\mathrm{V}_{\max }$ were found between both groups $(0.048 \pm 0.009$ vs $0.094 \pm 0.035 \mathrm{pmol}$ glucose/ng DNA/min, not significant) (Fig. 3B).

On the other hand, the glucose phosphorylation ratio measured at 1 and $100 \mathrm{mM}$ glucose was significantly higher in S5 than in C5 hamsters $(0.26 \pm 0.02$ vs $0 \cdot 11 \pm 0 \cdot 01, P<0 \cdot 005)$, suggesting a higher hexokinase/ glucokinase activity ratio in S5 animals. Such a difference could be attributed to an increased hexokinase activity in S5 animals.

\section{DNA content}

The DNA content of islets isolated from C5 and S5 hamsters was $57 \pm 2 \cdot 85$ and $41 \cdot 5 \pm 2 \cdot 02 \mathrm{ng} \mathrm{DNA} /$ islet respectively $(P<0 \cdot 005)$. Thus, islets from $\mathrm{C} 5$ animals would have a larger number of cells than those from S5 hamsters. 


\section{Discussion}

Our results show that islet $\beta$-cells from sucrose-treated animals released more insulin than those from control animals, in the presence of low or high glucose. This effect was observed either in vitro or in vivo (normoglycaemia with hyperinsulinaemia), and is in agreement with that previously reported by our group using the same experimental model (Massa et al. 1997, Del Zotto et al. 1999). These functional changes were accompanied by a significant increase $(100 \%)$ in the $\beta$-cell mass due to an increased $\beta$-cell replication rate and islet neogenesis without changes in the percentage of $\alpha$ - and $\beta$-cells (Massa et al. 1997, Del Zotto et al. 1999, 2000). The latter process resulted in an increment of small-sized islets, which is reflected in the current experiments in the lower DNA content measured in S5 islets. Sucrose-induced insulin resistance might be the underlying mechanism that triggered these functional and morphological $\beta$-cell changes (Massa et al. 1997, Del Zotto et al. 1999, 2000).

Glucose stimulates insulin secretion in a dose-response sigmoidal fashion (Ashcroft et al. 1970), and the shape of this curve follows the same pattern as that of glucose phosphorylation in the islets (Ashcroft et al. 1970, Matschinsky 1990).

Glucose phosphorylation is the rate-limiting step for glucose metabolism and for triggering the release of insulin (Lenzen \& Panten 1988, Matschinsky 1990, Lenzen 1992). It is accomplished by two different enzymes, with high and low affinity for glucose (hexokinase and glucokinase respectively) (Lenzen \& Panten 1988). The presence of these two kinases in $\beta$-cells enables the islets to effectively phosphorylate glucose in the presence of a wide range of glucose concentrations, adjusting appropriately the release of insulin to the actual glucose level.

Changes in the release of insulin are accompanied by simultaneous changes in glucose metabolism (and islet phosphorylating activity), as it occurs in different physiological conditions, such as pregnancy (Brelje \& Sorenson 1988, Cockburn et al. 1997), and in several experimental conditions characterized by $\beta$-cell overload and hyperglycaemia (Loubatieres 1964, Lee et al. 1989, Epstein et al. 1992, Becker et al. 1996, Leahy 1996). In such circumstances, $\beta$-cells undergo a simultaneous increase in glucose sensitivity and responsiveness, in glucose metabolism and in the hexokinase/glucokinase ratio. The islets from our sucrose-treated hamsters showed all these features, namely, a higher release of insulin in response to glucose, together with an increased glucose metabolism and hexokinase/glucokinase ratio, but in the presence of normal blood glucose levels. Therefore, the overload of $\beta$-cells per se rather than hyperglycaemia would trigger the changes in $\beta$-cell function.

The hexokinase/glucokinase ratio in S5 animals increased 279 times compared with controls; the magnitude of this increment was similar to that reported by
Hosokawa et al. (1995) in islets from 90\% pancreatectomized rats. The $25 \%$ increase in islet hexokinase $\mathrm{V}_{\max }$ measured in our S5 animals - comparable with that stated by Hosokawa et al. (1995) - without concomitant changes in glucokinase activity, can account for the increased hexokinase/glucokinase ratio, and in time for the increased glucose metabolism and $\beta$-cell hypersensitivity and hyper-responsiveness to glucose. The fact that hexokinase overexpression in $\beta$-cells (Epstein et al. 1992, Becker et al. 1996) induces similar changes in their secretory function lends support to the latter assumption.

Together, these results reinforce the concept that (a) under conditions of $\beta$-cell overload, hexokinase partially takes control over the glucose set-point for insulin secretion, causing the $\beta$-cell hypersensitivity to glucose (Lenzen \& Panten 1988, Epstein et al. 1992, Lenzen 1992, Newgard 1992, Hosokawa et al. 1995, Leahy 1996), and (b) hexokinase is metabolically more active than glucokinase to up-regulate the $\beta$-cell function. Consequently, it could be assumed that sucrose induces an increase in the hexokinase/glucokinase activity ratio in the islets, which is responsible for the increase in $\beta$-cell glucose metabolism, and in the $\beta$-cell sensitivity and responsiveness to glucose. These changes make the islets capable of overcoming the increased demand of insulin - elicited by sucrose feeding - keeping blood glucose levels within a normal range at the expense of an increased release of insulin (hyperinsulinaemia), characteristic of the insulin-resistant state (Reaven 1988).

In our model, the morphological and functional changes depicted in the islets were accompanied by a significant increment in the mass of INGAP-positive cells (Del Zotto et al. 2000). It remains to be demonstrated whether this compound might also play a role in the control of the metabolic changes currently described.

\section{Acknowledgements}

We thank Mrs Adriana Di Maggio for excellent secretarial support, Mr Adrián Díaz for technical assistance and Dr Luis Flores for his collaboration in the analysis of the results. This study was supported by funds provided by CONICET, FONCYT and CICPBA.

\section{References}

Ashcroft SJH, Hedeskov PJ \& Randle PJ 1970 Glucose metabolism in mouse pancreatic islets. Biochemical Journal 118 143-154.

Becker TC, Noel RJ, Johnson JH, Lynch RM, Hirose H, Tokuyama Y, Bell GI \& Newgard CB 1996 Differential effects of overexpressed glucokinase and hexokinase I in isolated islets. Evidence for functional segregation of the high and low $\mathrm{Km}$ enzymes. Journal of Biological Chemistry 271 390-394.

Brelje TC \& Sorenson RL 1988 Nutrient and hormonal regulation of the threshold of glucose-stimulated insulin secretion in isolated rat pancreases. Endocrinology 123 1582-1590. 
Cockburn BN, Ostrega DM, Sturis J, Kubstrup C, Polonsky KS \& Bell GI 1997 Changes in pancreatic islet glucokinase and hexokinase activities with increasing age, obesity, and the onset of diabetes. Diabetes 46 1434-1439.

DeFronzo RA 1997 Pathogenesis of type 2 diabetes: metabolic and molecular implications for identifying diabetes genes. Diabetes Reviews 5 177-269.

Del Zotto H, Massa L, Gómez Dumm CL \& Gagliardino JJ 1999 Changes induced by sucrose administration upon the morphology and function of pancreatic islets in the normal hamster. Diabetes/ Metabolism Research and Reviews 15 106-112.

Del Zotto H, Massa L, Rafaeloff R, Pittenger GL, Vinik A, Gold G, Reifel-Miller A \& Gagliardino JJ 2000 Possible relationship between changes in islet neogenesis and islet neogenesis-associated protein-positive cell mass induced by sucrose administration to normal hamsters. Journal of Endocrinology 165 725-733.

Epstein PN, Boschero AC, Atwater I, Cai X \& Overbeek PA 1992 Expression of yeast hexokinase in pancreatic $\beta$ cells of transgenic mice reduces blood glucose, enhances insulin secretion and decreases diabetes. PNAS 89 12038-12042.

Gagliardino JJ, Nierle C \& Pfeiffer EF 1974 The effect of serotonin on in vitro insulin secretion and biosynthesis in mice. Diabetologia 10 411-414.

Giroix MH, Sener A, Pipeleers DG \& Malaisse WL 1984 Hexose metabolism in pancreatic islets. Inhibition of hexokinase. Biochemical Journal 223 447-453.

Herbert V, Lau KS, Gottlieb CW \& Bleicher SJ 1965 Coated charcoal immunoassay of insulin. Journal of Clinical Endocrinology and Metabolism 25 1375-1384.

Hosokawa H, Hosokawa YA \& Leahy JL 1995 Upregulated hexokinase activity in isolated islets from diabetic $90 \%$ pancreatectomized rats. Diabetes 44 1328-1333.

Labarca C \& Paigen K 1980 A simple, rapid and sensitive DNA assay procedure. Analytical Biochemistry 102 344-352.

Lacy PE \& Kostianovsky M 1967 Method for the isolation of intact islets of Langerhans from the rat pancreas. Diabetes 16 35-39.

Leahy JL 1996 Impaired B-cell function with chronic hyperglycemia: 'Overworked $\beta$-cell' hypothesis. Diabetes Reviews 4 298-319.

Lee HC, Bonner-Weir S, Weir GC \& Leahy JL 1989 Compensatory adaptation to partial pancreatectomy in the rat. Endocrinology 124 1571-1575.

Lenzen S 1992 Glucokinase: signal recognition enzyme for glucoseinduced insulin secretion. In Nutrient Regulation of Insulin Secretion, pp 101-125. Ed. PR Flatt. London: Portland Press.

Lenzen S \& Panten U 1988 Signal recognition by pancreatic B-cells. Biochemical Pharmacology 37 371-378.

Like AA \& Chick WL 1970 Studies in the diabetic mutant mouse. I. Light microscopy and radioautography of pancreatic islets. Diabetologia 6 207-215.

Linde S, Hansen B \& Lernmark A 1980 Stable iodinated polypeptide hormones prepared by polyacrylamide gel electrophoresis. Analytical Biochemistry 107 165-176.

Lombardo YB, Chicco A, Mocchiutti N, de Rodi MA, Nusimovich B \& Gutman R 1983 Effect of sucrose diet on insulin secretion in vivo and in vitro and on triglyceride storage and mobilisation of the heart of rats. Hormone and Metabolic Research 15 69-76.
Lombardo YB, Drago S, Chicco A, Fainstein-Day P, Gutman R, Gagliardino JJ \& Gómez Dumm CL 1996 Long-term administration of a sucrose-rich diet to normal rats: relationship between metabolic and hormonal profiles and morphological changes in the endocrine pancreas. Metabolism 45 1527-1532.

Loubatieres A 1964 Effects of prolonged administration of hypoglycemic sulfonamide (chlorpropamide) on the subtotally pancreatectomized dog. In The Structure and Metabolism of the Pancreatic Islets, pp 437-450. Eds SE Brolin, B Hellman \& H Knutson. New York: The Macmillan Company.

Luo J, Quan J, Tsai J, Hobensack C, Sullivan C, Hector R \& Reaven GM 1998 Nongenetic mouse models of non-insulin-dependent diabetes mellitus. Metabolism 47 663-668.

Malaisse WJ \& Sener A 1988 Hexose metabolism in pancreatic islets. Feedback control of D-glucose oxidation by functional events. Biochimica et Biophysica Acta 971 246-254.

Massa L, Del Zotto H, Gómez Dumm CL \& Gagliardino JJ 1997 Postnatal sequential changes in islet morphology and insulin secretion of normal hamsters. Pancreas 14 58-64.

Matschinsky FM 1990 Glucokinase as glucose sensor and metabolic signal generator in pancreatic beta-cells and hepatocytes. Diabetes 39 $647-652$.

Newgard CB 1992 Cellular engineering for the treatment of metabolic disorders: prospects for therapy in diabetes. Biotechnology $\mathbf{1 0}$ 1112-1120.

Parsons JA, Brelje TC \& Sorenson RL 1992 Adaptation of islets of Langerhans to pregnancy: increased islet cell proliferation and insulin secretion correlates with the onset of placental lactogen secretion. Endocrinology 130 1459-1466.

Pick A, Clark J, Kubstrup CH, Levisetti M, Pugh W, Bonner-Weir S \& Polonsky KS 1998 Role of apoptosis in failure of beta cell mass compensation for insulin resistance and beta cell defects in the male Zucker diabetic fatty rat. Diabetes 47 358-364.

Reaven GM 1988 Role of insulin resistance in human disease. Diabetes 37 1595-1607.

Stauffacher W, Orci L, Amherdt M, Burr IM, Balant L, Froesch ER \& Renold AE 1970 Metabolic state, pancreatic insulin content and B-cell morphology of normoglycemic spiny mice (Acomys cahirinus): indications for an impairment of insulin secretion. Diabetologia 6 330-342.

Thorens B, Charron MJ \& Lodish HF 1990 Molecular physiology of glucose transporters. Diabetes Care 13 209-218.

Vinik A, Pittenger G, Rafaeloff R, Rosenberg L \& Duguid W 1996 Determinants of pancreatic islet cell mass: a balance between neogenesis and senescence/apoptosis. Diabetes Reviews 4 235-263.

Vinik A, Rafaeloff R, Pittenger G, Rosenberg L \& Duguid W 1997 Induction of pancreatic islet neogenesis. Hormone and Metabolic Research $29278-293$.

Received in final form 20 August 2001

Accepted 28 August 2001 